\title{
戸建て住宅における用途別使用水量の推定に関する研究 A STUDY ON THE POSSIBILITY OF PREDICTION
FOR THE WATER USAGE IN A HOUSE
}

浅野良晴*1, 野本 健 太*2, 市川憲良*3, 浅野 美代子*4 Yoshiharu ASANO, Kenta NOMOTO, Noriyoshi ICHIKAWA and Miyoko ASANO

In this paper the authors investigated the water usage in a house. It is difficult to install the flowmeters at every branch in order to measure the used quantities of water in a residence, because of technical difficulty and economical burden. The authors constructed the neural network model predicting water usage in each purpose at selected 5 residences. The authors calculated the statistical quantities in all water usage, and could predict the total amount of water usage in each purpose.

Keywords : residence, total amount of water usage in each purpose, flux distribution, prediction, neural network

住宅、用途別使用水量、流量分布、推定、ニューラルネットワーク

1.はじめに

我が国の多くの都市において、人口の集中化や水使用原単位の増 大により水不足が重大な問題 ${ }^{1}$ になってきている。その対策として住 宅において節水の呼びかけがされているが、それによりどの程度の 効果が期待できるか予測しなければならず、用途別使用水量を把握 する必要にせまられている。しかし、用途別使用水量の実態調査 ${ }^{2)}$ に は多くの困難を伴い、現在のところ十分に行われてはいない。

住宅において用途別に使用水量を計測する場合、すべての器具に 流量計を設置して実測調査 ${ }^{3)}$ を行うことになるが、居住している住宅 に計器類を取り付けるには困難な点が多数あるとともに、居住者の プライバシーの保護を考えたときに様々な問題が指摘されている。 一方、最近の住宅では引き込み管にパルス発信型の水道メーターを 取り付け、短い時間間隔での使用水量を計測し、それによって流量 変動のデー夕を記録することが可能()となってきている。この流量変 動データにより用途別使用水量が推定出来れば、計測における困難 が大幅に軽減されることになる。このたび東京都水道局の協力によ り 1994 年 7 月 25 日から 10 月 6 日に 13 件の住宅で引き込み管での 流量と各末端器具での吐水流量を同時に測ったデータを使用させて もらうことが出来た。本論文ではそれらを使用し住宅における用途 別使用水量を把握するため、引き込み管に㧍ける流量変動から末端
の使用器具每の吐水流量予測を行うモデルの構築を行い、そのモデ ルの有用性を検討している。

本論文では、提供を受けたデータから選出したモニター住戸につ いて各用途別使用水量の時系列データの統計解析を行い、各用途別 水使用状況の特徵を把握した。そして、引き込み管での流れ始めか ら終わりまでを 1 回の水使用とし、その時系列データの統計量から 使用用途を推定するニューラルネットワークモデルの構築を行った。 そして学習終了後のモデルに各住戸の引き込み管における水使用デ 一タを使って用途別水量の推定結果を評価したところ、構築したも デルは、十分に汎用可能であることが分かった。

\section{2. 研究概要}

2.1 ニューラルネットワークの概要

本論文では用途別使用水量推定モデルの構築に際し、バックプロ バケーション法に基づく階層型ニューラルネットワークシミュレー ションプログラムを用いている。すなわち、構築したニューラルネ ットワークモデルで行っている学習方法は、教師データとネットワ ークによる出力值との差の二乗和を最小にするようにシナプス結合 荷重を調整するという非線形最小二乗問題ら)の解を求めることであり この最適化問題の解法のアルゴリズムとしては最急降下法を学習則
*1 信州大学工学部 教授・工博

*2 信州大学工学部 大学院生

*3 東京都立短期大学 教授・工博

*4 大東文化大学法学部 助教授・理修
Prof., Dept. of Architecture and Civil Engineering, Faculty of Eng., Shinsyu Univ., Dr. Eng.

Graduate Student, Dept. of Architecture and Civil Engineering, Faculty of Eng. Shinsyu Univ.

Prof., Dept. of Urban Life Science, Tokyo Metropolitan College, Dr. Eng. Assoc. Prof., Faculty of Law. Daitobunka Univ., M. Sc. 
に適用したバックプロパゲーション法を用いている。

この階層型ニューラルネットワークは入力層、中間層、出力層か らなり、隣の層のユニット間は全て結合しているものとし、それ以 外の層のユニットとの結合はない。入力層と中間層には入力を受け ずに常に 1 を出力するバイアスニューロンを 1 個含め持っている。 図1のようになっているユニット $\mathrm{j}$ に前層のユニット i からら出力 $\mathrm{o}_{\mathrm{i}}$ が入力 $x_{i}$ として与えられると、ユニット間のシナプス結合荷重 $\mathrm{w}_{\mathrm{ji}}$ に より、このユニットの内部状態 $u_{\mathrm{j}} か ゙(1)$ 式のように計算される。

$$
u_{\lrcorner}=\sum_{i} W_{j i} X_{i} \cdots \cdots \cdot
$$

そしてこの $u_{\mathrm{j}}$ を次式に示すシグモイド関数で変換した值がそのב ニットからの出力yとなる。

$$
\begin{gathered}
f(u)=\frac{1}{1+\exp (-u)} \cdots \cdot . \\
y=f(u) \quad \cdots . .
\end{gathered}
$$

また、ニューラルネットワークモデルの中間層ユニット数は学習 精度と学習速度に関与している。本論文では誤差関数值 (rms) およ び情報量規隻 ${ }^{6)}$ (AIC) を用いて中間層のユニット数についての検討 を行った。rms およびAICの式を以下に示す。

$$
r m s=\sqrt{\frac{S S Q}{n}}
$$

$\mathrm{AIC}=-2 \times \mathrm{MLL}+2 \times \mathrm{k}$

$$
\begin{aligned}
& \mathrm{rms} \text { : 誤差関数值 } \quad \text { MLL : 最大対数尤度 } \\
& \text { SSQ : 2 乗誤差の和 } \mathrm{k} \text { : パラメータ数 } \\
& \mathrm{n}: \text { デ一夕数 }
\end{aligned}
$$

モデルの学習には各用途別使用水量の時系列データの統計量を教 師データとして使用している。そして、ニューラルネットワークの 学習アルゴリズムを繰り返し得られた学習終了時におけるシナプス 結合荷重を基に、6 系統の用途に出力するモデルを構築した。

\section{2. 解析対象住宅の概要}

本論文では前述のように東京都水道局が 1994 年 7 月 25 日から 10 月 6 日に行った 13 件の戸建住宅を調査した各用途別使用水量データ を使用している。その内容はモニター住宅における全水使用器具に パルス発信型流量計を設置し、0.01 L / pulse の精度で計測し、1 秒 毎にデータの記録を行ったものである。

各住宅における用途別 24 時間使用水量の 8 月、9月の平均を表 1 に示す。特徵としては風呂、トイレおよび台所系統における使用水
量が多く総使用水量は居住者数に比例して大きくなっていく傾向が

\begin{tabular}{|c|c|c|c|c|c|c|c|c|}
\hline \multicolumn{2}{|c|}{ 居住者数 } & 台所 & 風呂 & 洗面所 & 洗濯 & トイレ & その他 & 合計 \\
\hline \multirow{4}{*}{ 2人 } & $\mathrm{H}$ & $\begin{array}{l}69.3 \\
(20) \\
\end{array}$ & $\begin{array}{c}152.5 \\
(44)\end{array}$ & $\begin{array}{l}9.8 \\
\text { (3) }\end{array}$ & $\begin{array}{l}0.0 \\
(0)\end{array}$ & $\begin{array}{l}82.1 \\
(24)\end{array}$ & $\begin{array}{r}30.5 \\
(9)\end{array}$ & 344 \\
\hline & 1 & $\begin{array}{r}111.1 \\
(41)\end{array}$ & $\begin{array}{l}55.6 \\
(21)\end{array}$ & $\begin{array}{l}8.4 \\
\text { (3) }\end{array}$ & $\begin{array}{r}19.3 \\
(7)\end{array}$ & $\begin{array}{l}53.6 \\
(20)\end{array}$ & $\begin{array}{r}21.3 \\
(8)\end{array}$ & 269 \\
\hline & $\mathrm{N}$ & $\begin{array}{r}210.1 \\
(21)\end{array}$ & $\begin{array}{c}308.3 \\
(30)\end{array}$ & $\begin{array}{r}23.9 \\
(2)\end{array}$ & $\begin{array}{r}199.1 \\
(20)\end{array}$ & $\begin{array}{r}149.4 \\
(15)\end{array}$ & $\begin{array}{r}119.5 \\
(12)\end{array}$ & 1010 \\
\hline & $Q$ & $\begin{array}{c}157.3 \\
(28)\end{array}$ & $\begin{array}{c}124.0 \\
(22)\end{array}$ & $\begin{array}{c}35.6 \\
(6)\end{array}$ & $\begin{array}{l}74.3 \\
\text { (13) } \\
\end{array}$ & $\begin{array}{c}172.4 \\
(31) \\
\end{array}$ & $\begin{array}{l}0.2 \\
(0)\end{array}$ & 564 \\
\hline \multirow{4}{*}{ 3人 } & C & $\begin{array}{r}318.9 \\
(44) \\
\end{array}$ & $\begin{array}{r}278.1 \\
(38) \\
\end{array}$ & $\begin{array}{l}1.0 \\
(0)\end{array}$ & $\begin{array}{r}53.0 \\
(7) \\
\end{array}$ & $\begin{array}{l}69.0 \\
(10)\end{array}$ & \begin{tabular}{|l|}
5.6 \\
$(1)$
\end{tabular} & 7 \\
\hline & $\mathrm{D}$ & $\begin{array}{r}122.0 \\
(14)\end{array}$ & $\begin{array}{r}236.7 \\
(26)\end{array}$ & $\begin{array}{l}7.8 \\
\text { (1) }\end{array}$ & $\begin{array}{r}325.0 \\
(36)\end{array}$ & $\begin{array}{c}194.2 \\
(22)\end{array}$ & \begin{tabular}{l|}
8.9 \\
$(1)$
\end{tabular} & 895 \\
\hline & $\mathrm{K}$ & $\begin{array}{r}176.6 \\
(20) \\
\end{array}$ & $\begin{array}{c}156.4 \\
(17) \\
\end{array}$ & $\begin{array}{c}30.6 \\
(3)\end{array}$ & $\begin{array}{r}210.7 \\
(24)\end{array}$ & $\begin{array}{r}253.8 \\
(28) \\
\end{array}$ & $\begin{array}{r}67.2 \\
(8) \\
\end{array}$ & 89 \\
\hline & 0 & $\begin{array}{r}237.7 \\
(21) \\
\end{array}$ & $\begin{array}{r}146.5 \\
(13) \\
\end{array}$ & $\begin{array}{r}11.9 \\
(1)\end{array}$ & $\begin{array}{c}426.1 \\
(37) \\
\end{array}$ & $\begin{array}{r}275.1 \\
(24) \\
\end{array}$ & $\begin{array}{r}47.4 \\
(4) \\
\end{array}$ & 1145 \\
\hline \multirow{4}{*}{ 4人 } & B & $\begin{array}{r}251.8 \\
(23)\end{array}$ & $\begin{array}{c}352.4 \\
(32)\end{array}$ & $\begin{array}{l}10.5 \\
\text { (1) }\end{array}$ & $\begin{array}{c}311.3 \\
(28)\end{array}$ & $\begin{array}{c}167.9 \\
(15)\end{array}$ & $\begin{array}{l}5.4 \\
(1)\end{array}$ & 1099 \\
\hline & $\mathrm{E}$ & $\begin{array}{r}150.5 \\
(21) \\
\end{array}$ & $\begin{array}{c}172.3 \\
(24) \\
\end{array}$ & $\begin{array}{c}44.8 \\
(6)\end{array}$ & $\begin{array}{c}143.8 \\
(20)\end{array}$ & $\begin{array}{r}212.5 \\
(29)\end{array}$ & $\begin{array}{l}1.3 \\
(0)\end{array}$ & 725 \\
\hline & $J$ & \begin{tabular}{|l|}
73.1 \\
$(14)$
\end{tabular} & $\begin{array}{c}186.1 \\
(35)\end{array}$ & $\begin{array}{r}23.9 \\
(5)\end{array}$ & $\begin{array}{r}123.0 \\
(23)\end{array}$ & $\begin{array}{c}108.5 \\
(21)\end{array}$ & \begin{tabular}{|l|}
9.6 \\
$(2)$
\end{tabular} & 524 \\
\hline & $\mathrm{P}$ & $\begin{array}{r}28.7 \\
(20) \\
\end{array}$ & $\begin{array}{r}116.8 \\
(18) \\
\end{array}$ & $\begin{array}{l}62.2 \\
(10) \\
\end{array}$ & $\begin{array}{l}97.2 \\
(15) \\
\end{array}$ & $\begin{array}{r}236.6 \\
(36) \\
\end{array}$ & $\begin{array}{l}8.5 \\
(1)\end{array}$ & 650 \\
\hline 人 & A & $\begin{array}{r}309.5 \\
(22)\end{array}$ & $\begin{array}{c}554.8 \\
(40)\end{array}$ & $\begin{array}{r}79.9 \\
(6)\end{array}$ & $\begin{array}{c}257.2 \\
(19)\end{array}$ & $\begin{array}{r}143.9 \\
(10)\end{array}$ & $\begin{array}{r}35.4 \\
(3)\end{array}$ & 138 \\
\hline
\end{tabular}
見られた。しかしながら、各用途別使用水量は住宅により様々であ り、住宅における用途別使用水量の一般的な傾向を把握するために

\begin{tabular}{|c|c|c|c|c|}
\hline 住宅 & 階数 & 居住者数 & 家族構成：性別、年龄 & 居住年 \\
\hline A & 1階 & 5人 & 男61 女51 女23 女22 女20 & 16年 \\
\hline E & 2階 & 4人 & 男53 女49 女23 女21 & 17年 \\
\hline $\mathrm{K}$ & 1階 & 3人 & 男72 女66 女7 & 6年 \\
\hline $\mathrm{P}$ & 2階 & 4人 & 男59 女56 女28 男24 & 13年 \\
\hline Q & 2階 & 2人 & 男73 女72 & 23年 \\
\hline
\end{tabular}
は統計的に整理する必要がある。

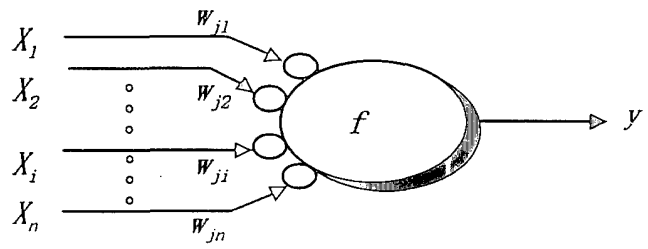

\begin{tabular}{|c|c|c|c|c|c|c|c|c|c|c|c|c|c|c|c|c|}
\hline \multirow{2}{*}{ 住宅 } & \multicolumn{2}{|c|}{ 台所 } & \multicolumn{2}{|c|}{ 風呂洗い場 } & \multicolumn{2}{|c|}{ 風呂浴槽 } & \multicolumn{2}{|c|}{ 洗面台 1 階 } & \multicolumn{2}{|c|}{ 洗面台2階 } & \multicolumn{2}{|c|}{ 洗濯 } & \multicolumn{2}{|c|}{ トイレ } & \multirow{2}{*}{ その他 } & \multirow{2}{*}{ 合計 } \\
\hline & 水 & 港。 & 水 & 8 & 水 & 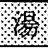 & 水 & 8 & 水 & i & 水 & 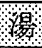 & 1階 & 2階 & & \\
\hline $\mathrm{A}$ & 0 & 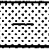 & 0 & 10 & 0 & 8 & 0 & $\$$ & - & \% & 0 & 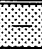 & 0 & - & 0 & 10 \\
\hline$E$ & 0 & $1 \%$ & 0 & 8 & 0 & $1 \%$ & 0 & $1 \%$ & 0 & $1 \%$ & 0 & 1 & 0 & 0 & 0 & 12 \\
\hline $\mathrm{K}$ & $\mathrm{O}$ & 18 & 0 & 0 & 0 & 1 & 0 & 18 & - & ? & 0 & 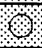 & 0 & - & 0 & 12 \\
\hline$P$ & 0 & 18 & 0 & 8 & 0 & 8 & 0 & 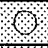 & 0 & 8 & 0 & 10 & 0 & 0 & 0 & 15 \\
\hline Q & 0 & 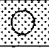 & 0 & 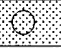 & - & 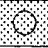 & 0 & 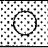 & - & ২ & 0 & ? & 0 & 0 & 0 & 11 \\
\hline
\end{tabular}

図 1 ニューロンのユニット $j$ における信号伝達モデル

表 1 用途別 24 時間平均使用水量 (8月、9 月)

表 2 解析対象住宅の属性

表 3 各住宅の流量計設置場所 
各住宅の居住者数より 6 個の用途別使用水量を変数としてクラス ター分析を行い、その結果からそれぞれを代表する住宅としてA、E、 K、P、Qの 5 件を選択し、解析の対象とした。対象とする 5 件の住宅 の居住者属性を表 2 に示し、流量計設置場所を表 3 に示寸。使用用 途として台所、風呂、洗面、洗濯、トイレ、その他の 6 種類に分類 して解析を行った。

更に、用途別使用水量および用途別流量分布に対して再度クラス ター分析を行い、対象とした 5 件の各住宅を代表する 3 日分を選択 した。これらの日は各住宅の平均的水使用状況に近いものである。 それらの合計 15 日分のデータに対して 1 回の水使用每に整理し、統 計量を求め、用途別使用水量を推定するニューラルネットワークモ デルの検討を行った。

\section{3. 水使用用途推定モデルの構築}

3.1 個別の住宅に対応するモデルの構築

個別の住宅に対応するモデルとして、入力層、中間層、出力層が 各 1 層の 3 層階層型ニューラルネットワークを構築した。入力層の 説明変数は 1 回の水使用毎の使用時間、使用水量、流量分布の標淮 偏差と推定最大值の 4 種類の統計量とした。出力層の変数は台所、 風呂、洗面、洗濯、トイレ、その他の 6 項目の各用途別使用割合で あり、その出力值は 6 個の出力值の合計が 1 となるように、それぞ れが 0 からら 1 の値を出力する。ここで 1 回の水使用において使用時 間が 5 秒以下である場合の使用水量の合計值は全体使用水量の $1 \%$ 未 満であり、かつ標本数が少ないデータでは使用用途による特徵が表 れていないことから 5 秒以下の水使用のデータは教師データから除 外した。

$\mathrm{A}$ 住宅の場合について述べる。A 住宅の水使用 2 ケ月分のデータを 用いクラスター分析し、代表となる 8 月 1 日、7 日の 2 日分 286 回の 水使用データを教師值として、構筑したモデルの学習を行った。説 明変数の最大值上して標本最大值ではなく、母集団の推定を行い推 定分布の 99\%最大值を用いた。入力層のデータは統計量毎に0〜1の 值となるように線形変換により規準化を行っている。これらのデー タにより学習を行った結果、中間層ユニットの数は誤差関数值 (rms) の值を最小とし、かつ情報量基隻（AIC）を最小とする場合の 12 個 とした。この A 住宅に対する水使用用途推定モデルを用いて 8 月 19 日のデータをテストデータとしてモデルの評価を行った。

\section{2 褛数の住宅に対応する汎用モデルの構築}

汎用性を高めるため、選択した 5 件の住宅に対応する汎用モデル の構築を行った。そのニューラルネットワークを図 2 に示す。個別 の住宅に対するモデルと比心゙ると、入力層の説明変数は水使用毎の 統計量だけでなく、住宅の属性を示す項目として居住者数を加えた 5 項目とした。出力層の変数は個別住宅モデルと同様の 6 項目である。

各住宅 2 日分のデータを学習に用いた。個別の住宅モデルと同様 に使用時間が 5 秒以下のデータは除外し、5 件の住宅の全 864 回の水 使用デー夕を用いて汎用モデルの学習を行った。中間層ユニットの 数はrms の值を最小とし、かつAICの値が最小となった 11 個とした。 学習が終了した汎用モデルに対して各住宅毎に 1 日ずつのデータを テストデータとして用いてモデルの評価を行った。

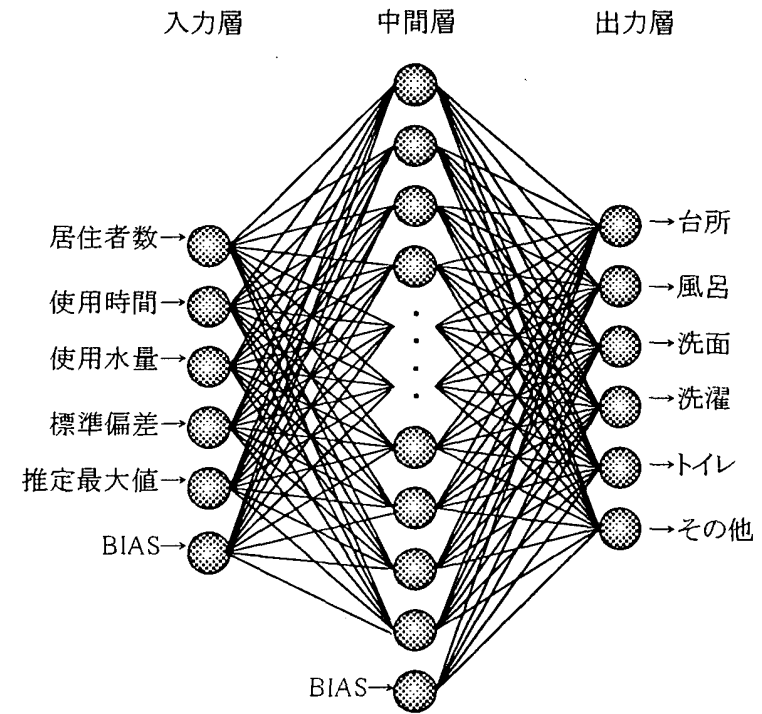

図 2 ニューラルネットワーク図（汎用モデル）

表 4 各住宅代表日の用途別使用水量 [ L/日 ]

\begin{tabular}{|c|c|c|c|c|c|c|c|c|}
\hline 宅 & 日付 & 台所 & 風呂 & 洗面 & 洗濯 & トイレ & その他 & 合計 \\
\hline \multirow{3}{*}{ A } & 月1日 & 47.2 & 494.7 & 83.5 & 371.8 & 115.8 & 183.0 & 1596 \\
\hline & 8月7日 & 378.9 & 666.6 & 93.9 & 188.7 & 120.5 & 90.3 & 1539 \\
\hline & 8月19日 & 264.9 & 816.5 & 79.8 & 230.4 & 157.6 & 33.9 & 1583 \\
\hline \multirow{3}{*}{$E$} & 8月5日 & 88.1 & 218.1 & 53.5 & 80.9 & 232.2 & 1.4 & 674 \\
\hline & 8月8日 & 75.0 & 151.5 & 56.8 & 121.3 & 168.9 & 0.3 & 574 \\
\hline & 8月15日 & 49.1 & 321.2 & 44.9 & 97.4 & 176.3 & 0.2 & 685 \\
\hline \multirow{3}{*}{ K } & 8月5日 & 305.9 & 106.6 & 33.4 & 114.7 & 227.9 & 72.5 & 861 \\
\hline & 8月6日 & 259.7 & 84.5 & 26.6 & 119.0 & 280.9 & 37.3 & 808 \\
\hline & 8月7日 & 171.3 & 119.9 & 25.1 & 112.6 & 267.0 & 55.1 & 751 \\
\hline & 8月5日 & 157.1 & 127.4 & 52.9 & 79.3 & 212.1 & 9.1 & 638 \\
\hline & 8月9日 & 118.6 & 134.6 & 53.9 & 88.9 & 190.1 & 20.9 & 607 \\
\hline & 8月15日 & 121.1 & 84.6 & 43.7 & 92.1 & 268.0 & 7.2 & 617 \\
\hline & 8月5日 & 108.7 & 222.9 & 25.2 & 74.1 & 140.9 & 1.2 & 573 \\
\hline & 8月 15 日 & 147.4 & 157.5 & 27.1 & 122.4 & 104.9 & 0.2 & 560 \\
\hline & 8月 17 日 & 133.9 & 121.0 & 34.1 & 184.6 & 97.8 & 0.0 & 571 \\
\hline
\end{tabular}

表 5 各住宅代表日の用途別水使用回数［回/日］

\begin{tabular}{|c|c|c|c|c|c|c|c|c|}
\hline 住宅 & 日付 & 台所 & 風呂 & 洗面 & 洗濯 & トイレ & その他 & 合計 \\
\hline \multirow{3}{*}{ A } & 8月1日 & 108 & 15 & 40 & 9 & 14 & 4 & 190 \\
\hline & 8月7日 & 98 & 30 & 43 & 5 & 14 & 6 & 196 \\
\hline & 8月19日 & 78 & 20 & 42 & 7 & 19 & 2 & 168 \\
\hline \multirow{3}{*}{$E$} & 8月5日 & 48 & 3 & 27 & 3 & 11 & 3 & 95 \\
\hline & 8月8日 & 48 & 2 & 19 & 5 & 8 & 1 & 83 \\
\hline & 8月15日 & 43 & 6 & 24 & 4 & 7 & 2 & 86 \\
\hline \multirow{3}{*}{ K } & 8月5日 & 88 & 8 & 39 & 2 & 20 & 7 & 164 \\
\hline & 8月6日 & 87 & 14 & 37 & 2 & 23 & 6 & 169 \\
\hline & 8月7日 & 52 & 8 & 39 & 2 & 25 & 6 & 132 \\
\hline \multirow{3}{*}{ P } & 8月5日 & 93 & 3 & 24 & 2 & 33 & 1 & 156 \\
\hline & 8月9日 & 97 & 14 & 30 & 3 & 36 & 7 & 187 \\
\hline & 8月 15 日 & 87 & 17 & 35 & 3 & 47 & 2 & 191 \\
\hline \multirow{3}{*}{ Q } & 8月5日 & 51 & 11 & 22 & 6 & 21 & 2 & 113 \\
\hline & 8月 15 日 & 66 & 16 & 23 & 8 & 16 & 1 & 130 \\
\hline & 8 月 17 日 & 73 & 10 & 23 & 11 & 15 & 0 & 132 \\
\hline
\end{tabular}


4. 使用水量の統計処理結果

\section{1 用途別使用水量}

モデル構筑の対象となる 5 件の住宅について、夏期の用途別水使 用状況を把握するために 8 月 1 日（月）〜21日（日）において 24 時 間の用途別使用水量を求めた。これらの日の中で、風呂または洗濯 系統で水を使用しない日があったのでそれらの日は除外した。次に 残りの日において用途毎の水の使い方についてクラスター分析をお こない各住宅を代表するとみられる3 日分を選択した。

各住宅の水使用を代表する 3 日分の用途別水使用量を表 4 に示す。 それらは各住宅毎に特徵がみられた。すなわち A 住宅は台所および 風呂系統、 $\mathrm{E}$ 住宅は風呂およびトイレ系統、 $\mathrm{K}$ 住宅は台所およびトイ レ系統、P 住宅はトイレ系統、Q 住宅は風呂系統において使用水量が 多くなっている。しかし洗面系統の水使用量はどの住宅においても 少なかった。

次に用途別使用回数を表 5 に示す。 5 件の住宅のすべてで台所系 統の水使用回数が一番多かった。洗濯系統においては 1 回洗濯を行 う際の水使用回数が住宅により異なっている。これは使用している 洗濯機の機種が違っているからである。

\section{2 用途別の流量変動}

各住宅の用途別の流量分布を図 3 に示し、その平均流量および標 準偏差を表 6 に示す。風呂系統での流量変動は住宅によって差が大 きく7〜14L/min にピークがみられた。洗濯系統では A、E、P 住宅で は 10L/min 前後に、K 住宅では 15〜17L/min、Q 住宅では 8〜 10L/min にピーク流量がみられた。また、ほぼ一定の流量で使われることが 多く、標準偏差も小さくなっている。トイレ系統では A 住宅では 3L/min、E 住宅では 4L/min 上 $18 \mathrm{~L} / \mathrm{min} 、 K$ 住宅では $2 \mathrm{~L} / \mathrm{min}$ と $18 \mathrm{~L} / \mathrm{min}$ 、 $\mathrm{P}$ 住宅では 8L/min、Q 住宅では 6L/min がピークとなり、住宅によっ ては流量のピークとなる箇所が2 ケ所となる場合があった。

次に用途毎の水使用 1 回当たりの統計量平均を住宅別に表 7 に示 す。台所および洗面系統ではおよそ 20 秒/回で使われ、約 2 Lの使用 水量が平均となっているが、台所での水使用は回数が多くその統計 量のバラツキが大きくなっている。風呂系統の平均使用水量は 10〜 $60 \mathrm{~L}$ となっているが、風呂に湯を張る時などには 1 回に多量の水使用 があり、統計量のバラツキは大きくなっている。トイレ系統では $\mathrm{P}$ 住宅および Q 住宅においてトイレでは器具が使用される前に 0.2 $0.3 \mathrm{~L}$ の水が流れる場合が多く、この 2 件の住宅ではトイレ系統の水 使用回数は居住者数に対して多くなっている。そのために平均使用 水量は少なくなっている。しかし器具使用 1 回当たりの使用水量は $\mathrm{A}$ 、

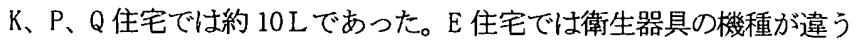
ため約 $23 \mathrm{~L} /$ 回の使用水量であった。

\section{5. 用途別使用水量の推定と結果}

\section{1 個別住宅モデルによる推定結果}

本論文で構築したニューラルネットワークモデルにより、A 住宅 を対象とした場合の用途別使用水量の推定を行った結果を述べる。 用途別使用水量推定の流れ図を図 4 に示す。ニューラルネットワー クモデルによる出力值は水使用用途毎の割合であるが、そこから更 に算定を進め、24 時間の用途別使用水量を求めた。推定結果を表 8
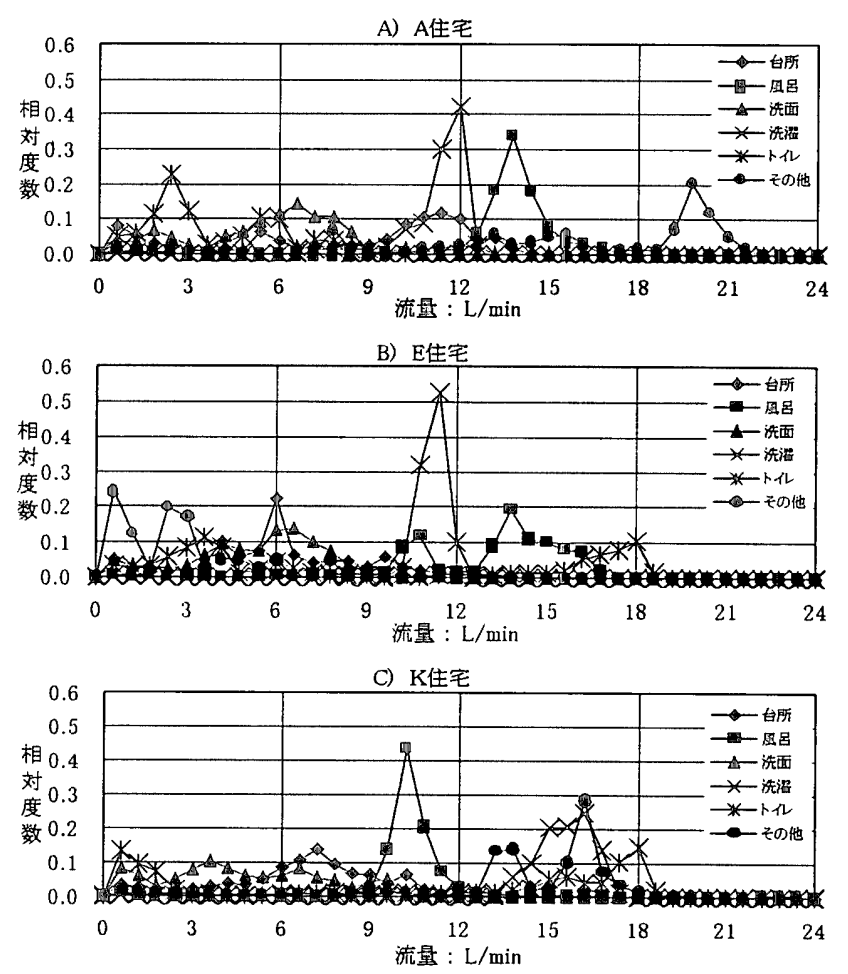

D) P住宅

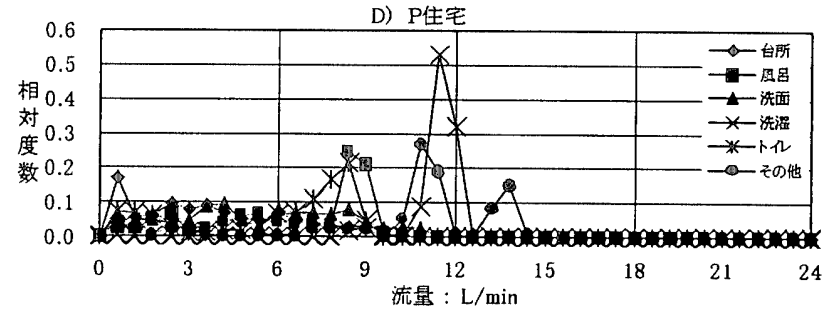

E) Q住宅

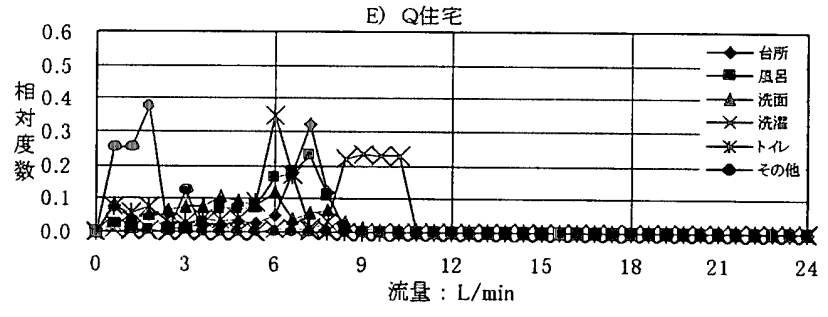

図 3 各住宅の用途別流量分布

表 6 各住宅の用途別水使用における平均流量と標準偏差 [L/min]

\begin{tabular}{|c|c|c|c|c|c|c|}
\hline & A住宅 & E住宅 & K住宅 & P住宅 & Q住宅 \\
\hline \multirow{2}{*}{ 台所 } & 平均流量 & 8.27 & 5.99 & 6.74 & 3.93 & 5.54 \\
\hline & 標淮偏差 & 4.13 & 2.74 & 2.78 & 2.62 & 2.40 \\
\hline \multirow{2}{*}{ 風呂 } & 平均流量 & 13.59 & 13.13 & 10.32 & 6.42 & 6.05 \\
\hline & 標準偏差 & 2.19 & 2.54 & 2.45 & 2.65 & 1.59 \\
\hline \multirow{2}{*}{ 洗面 } & 平均流量 & 5.51 & 5.32 & 4.90 & 5.40 & 4.49 \\
\hline & 標準偏差 & 2.34 & 2.17 & 2.72 & 2.84 & 2.29 \\
\hline \multirow{2}{*}{ 洗濯 } & 平均流量 & 11.17 & 11.05 & 15.36 & 11.30 & 8.96 \\
\hline & 標淮偏差 & 1.55 & 1.31 & 1.88 & 1.19 & 1.52 \\
\hline \multirow{2}{*}{ トイレ } & 平均流量 & 3.64 & 9.17 & 10.47 & 5.90 & 4.71 \\
\hline & 標淮偏差 & 2.02 & 6.52 & 7.16 & 2.82 & 2.06 \\
\hline \multirow{2}{*}{ その他 } & 平均流量 & 15.86 & 2.65 & 14.06 & 10.19 & 1.50 \\
\hline & 標淮偏差 & 4.99 & 1.95 & 3.88 & 3.60 & 0.79 \\
\hline
\end{tabular}


に示す。台所拉よび洗面系統における水使用は水使用每の統計量の 差は大きいが、使用回数が多くモデルの学習に使用したパターン数 が多かったために学習結果は良好であった。風呂系統は短時間の水 使用では䛊判別される場合が多かったが、長時間の水使用では正し く判別された。その結果、使用水量の推定值と実測值の差は小さく なった。洗濯およびトイレ系統は水の使用され方が類似していたた め同時使用がある場合に、誤判別される場合もあった。その他の系 統では水使用毎の統計量の差が大きく、学習に用いるパターン数も 少なかったために予測精度は低くかった。全般的には推定した用途 別使用水量は実測值と近い值を示した。A 住宅において今回構築した 個別住宅モデルを使って引き込み管での流量変動から用途別使用水 量を推定することができたものと考える。これは他の住宅において も同様であった。

\section{2 汎用モデルによる推定結果}

$A \sim Q$ 住宅の 5 件を対象として用途別使用水量の推定を行った結果 を述心゙る。個別モデルの場合と同様にニューラルネットワークモデ ルによる出力值の用途別使用割合から更に算定を進め 24 時間毎の用 途別使用水量を求めた。教師データ対する学習精度を図 5 に示す。 教師データに対する学習結果と実測值との重相関係数 $\mathrm{R}^{2}$ は 0.94 であ った。これにより住宅属性および水使用毎の統計量と用途別水使用 割合との関係を、構築したニューラルネットワークモデルにより学 習出来たと考える。

テストデータに対する推定結果を図6に示す。A 住宅の風呂系統、 $\mathrm{E}$ 住宅のトイレ系統、 $\mathrm{K}$ 住宅の台所系統、Q 住宅の洗濯系統において 推定值と実測值との差が大きいものの、それら以外の系統では推定 值と実測値は近い値となっていた。

そこで、用途毎にモデルによる推定值と実測值に差があるかどう か調べるために差の検定 ”を行った。ここでは差がないという帰無仮 説を立てて $\mathrm{t}$ 検定を行った。その結果を表 9 に示す。すべての用途 において $\mathrm{T}$ 值が $\mathrm{t}_{4}(0.025)=2.78$ より小さくなっており、有意水準 $5 \%$ では㷌無仮説を棄却することが出来なかった。よって、用途毎の推 定值と実測值とは母平均に差がないといえる。

次に $\mathrm{P}$ 住宅における各用途別水量の実測值と推定值の割合を図 7 に示す。洗濯とトイレ系統に若干の違いは見られるが、用途別使用

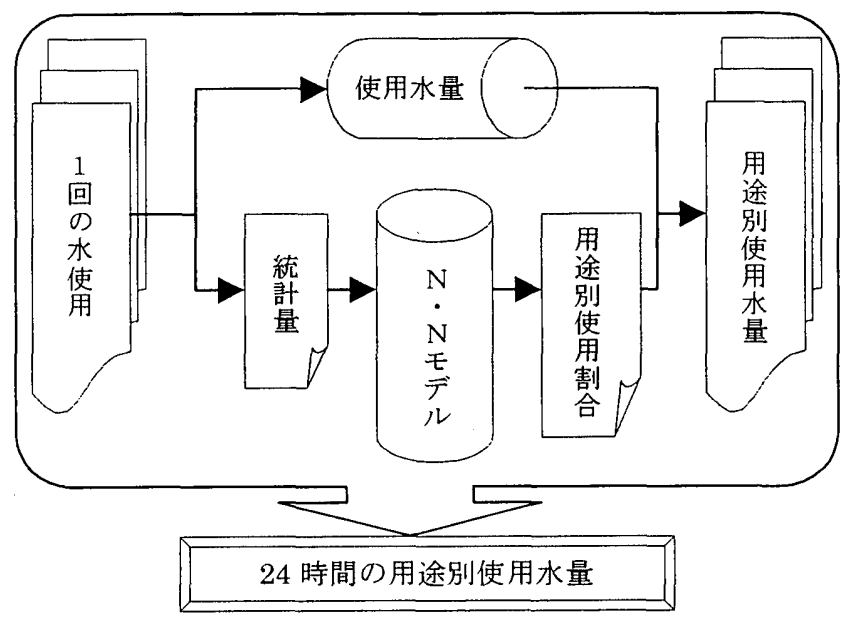

図 4 用途別使用水量推定の流れ図
表 7 住宅別用途別の水使用 1 回当たりの統計量平均

\begin{tabular}{|c|c|c|c|c|c|c|}
\hline 用途 & 住宅 & \begin{tabular}{|c|} 
平均 \\
{$[\mathrm{L} / \mathrm{min}]$}
\end{tabular} & \begin{tabular}{|c|} 
標淮偏差 \\
{$[\mathrm{L} / \mathrm{min}]$}
\end{tabular} & $\begin{array}{c}\text { 最大流量 } \\
{[\mathrm{L} / \mathrm{min}]} \\
\end{array}$ & \begin{tabular}{|c|}
$\begin{array}{c}\text { 使用水量 } \\
{[\mathrm{L}]}\end{array}$ \\
\end{tabular} & $\begin{array}{c}\begin{array}{c}\text { 使用時間 } \\
\text { [秒] }\end{array} \\
\end{array}$ \\
\hline \multirow{5}{*}{ 台所 } & A & 7.39 & 3.64 & 10.98 & 3.49 & 25.3 \\
\hline & $E$ & 5.69 & 2.22 & 7.53 & 1.51 & 15.3 \\
\hline & $\mathrm{K}$ & 6.12 & 2.53 & 8.67 & 3.25 & 28.9 \\
\hline & $P$ & 3.07 & 1.84 & 5.48 & 1.43 & 20.3 \\
\hline & Q & 4.80 & 1.75 & 6.31 & 2.07 & 22.6 \\
\hline \multirow{5}{*}{ 風呂 } & A & 12.66 & 3.28 & 15.99 & 32.01 & 134.4 \\
\hline & $\mathrm{E}$ & 11.83 & 2.63 & 17.17 & 67.33 & 287.0 \\
\hline & $\mathrm{K}$ & 10.46 & 2.82 & 14.27 & 11.45 & 60.3 \\
\hline & $P$ & 4.51 & 1.19 & 5.77 & 19.02 & 61.3 \\
\hline & $Q$ & 5.40 & 1.18 & 6.95 & 1.4 .07 & 81.9 \\
\hline \multirow{5}{*}{ 洗面 } & A & 5.57 & 1.86 & 7.30 & 2.06 & 22.4 \\
\hline & $\mathrm{E}$ & 4.61 & 1.37 & 5.94 & 2.28 & 25.0 \\
\hline & $K$ & 4.29 & 2.12 & 6.67 & 0.74 & 9.1 \\
\hline & $P$ & 4.84 & 1.86 & 6.81 & 1.75 & 17.1 \\
\hline & $\mathrm{Q}$ & 4.34 & 1.90 & 6.25 & 1.27 & 21.4 \\
\hline \multirow{5}{*}{ 洗濯 } & $\mathrm{A}$ & 10.90 & 3.24 & 16.67 & 37.32 & 202.2 \\
\hline & $\mathrm{E}$ & 10.36 & 2.86 & 16.83 & 25.19 & 135.6 \\
\hline & $K$ & 17.71 & 4.44 & 26.60 & 57.72 & 224.8 \\
\hline & $P$ & 11.26 & 1.46 & 13.43 & 33.33 & 172.8 \\
\hline & Q & 8.36 & 1.88 & 10.40 & 14.81 & 148.4 \\
\hline \multirow{5}{*}{ トイ } & A & 4.61 & 1.81 & 8.08 & 8.39 & 138.0 \\
\hline & $E$ & 11.31 & 5.00 & 18.45 & 22.46 & 145.2 \\
\hline & $\mathrm{K}$ & 10.38 & 6.70 & 17.74 & 11.43 & 65.4 \\
\hline & $P$ & 4.20 & 1.47 & 5.98 & 5.32 & 49.3 \\
\hline & Q & 4.29 & 1.65 & 6.40 & 6.60 & 85.3 \\
\hline \multirow{5}{*}{ その他 } & A & 14.90 & 4.26 & 19.23 & 25.92 & 96.8 \\
\hline & $E$ & 4.10 & 2.22 & 6.30 & 0.27 & 6.8 \\
\hline & K & 11.80 & 4.70 & 16.44 & 8.59 & 37.1 \\
\hline & $P$ & 10.19 & 3.15 & 12.17 & 5.21 & 20.2 \\
\hline & $\mathrm{Q}$ & 1.68 & 0.89 & 3.00 & 0.26 & 2.7 \\
\hline
\end{tabular}

表 8 個別モデルによる推定結果（A 住宅） [ L ]

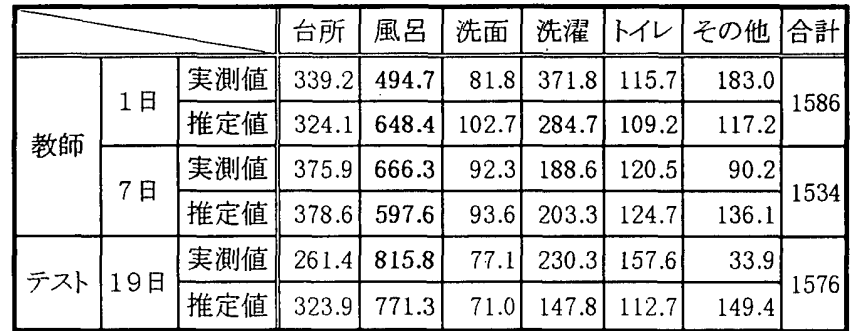

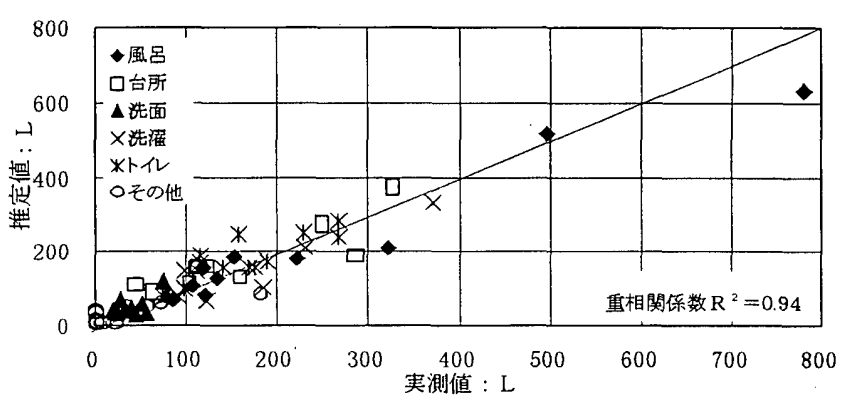

図 5 汎用モデルの学習精度 
割合は近い值となっている。以上より、構築した複数の住宅用モデ ルにより用途別使用水量を推定できたものと考える。

学習終了時の各ユニット間のシナプス結合荷重を表 10 に示す。入 力層ユニットと中間層ユニット間のシナプス結合荷重を見ると、入 力層「使用水量」のユニットからの結合荷重が一番大きく、続いて 「推定最大值」、「使用時間」の順に大きな值を示していたことか ら、これらが水使用用途の予測に大きく影響していると考える。一 方、「居住者数」のユニットからの結合荷重は小さくなっていた。

\section{6.まとめ}

本論文では、水使用毎の流量分布統計量から使用用途を推定する ニューラルネットワークモデルの構築を行った。そして、5 件の住宅 に対して行った各用途別使用水量調查の結果を構築したモデルに適 用し、用途別使用水量を推定した、そしてモデルの評価を行った結 果、以下に示すような知見が得られた。

(1) 推定された各用途別使用水量は 5 件の住宅に抽てそれぞれ固有 の特徽が見られたことから、この方法をより一般的にするために、 さらに多くの住宅において検証する必要がある。

（2）使用用途により 1 回の水使用時の流量分布には固有の特徴が見 られたことから、まず個別の住宅に対応するモデルに対し入力させ る説明变数を水使用每の「使用時間」、「使用水量」、「標準偏差」、 「推定最大值」として各用途別使用水量を推定する事ができた。

(3) 沉用モデルでは䙡数の住宅に対応させるため、説明変数に住宅の 属性を表す項目「居住者数」を加え、用途別使用水量のお抢まかな 比率は把握することができた。さらに予測精度を向上させるために は、器具の種類に関する項目を加えることが考えられ、今後の課題 としたい。

(4) 用途毎にみると、洗濯拉よびトイレ系統における水使用は使用水 量、流量が特徽的で、水使用毎の差が小さく推定し易い。しかし、 台所、風呂場拉よび洗面台采統における水使用は人の手により使用 水量、流量の調節が可能であり、水使用每の差が大きくなっていた。 風呂系統に㧈计る水使用は他の器具に比べ使用時間が長く、使用水 量も大きいため正答率が高く、実測值と推定值の違いは少なかった。

このことから本論文で示したモデルにより、住宅の用途別使用水 量の推定に関する可能性が示されたと考える。

同じ使用用途でも住宅により器具の種類が違う場合は流量の統計 量が異なってくることから、今後は説明変数に配管径や器具の種類 など住宅固有の属性值を加えていき、予測精度の向上をはかってい
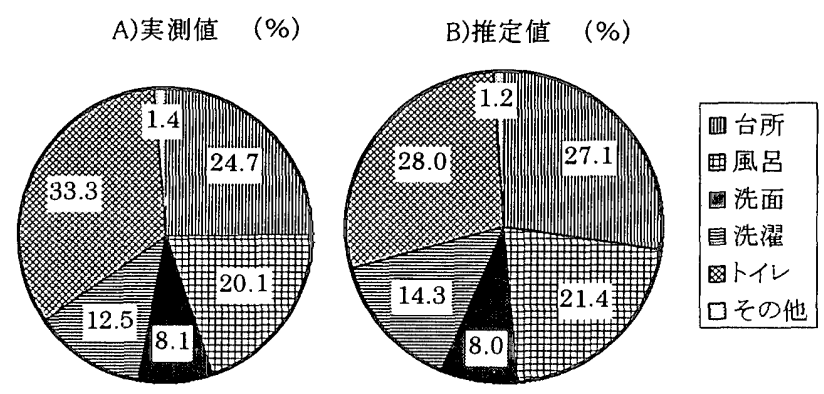

図 7 汎用モデルによる推定値（P住宅 8 月 5 日）
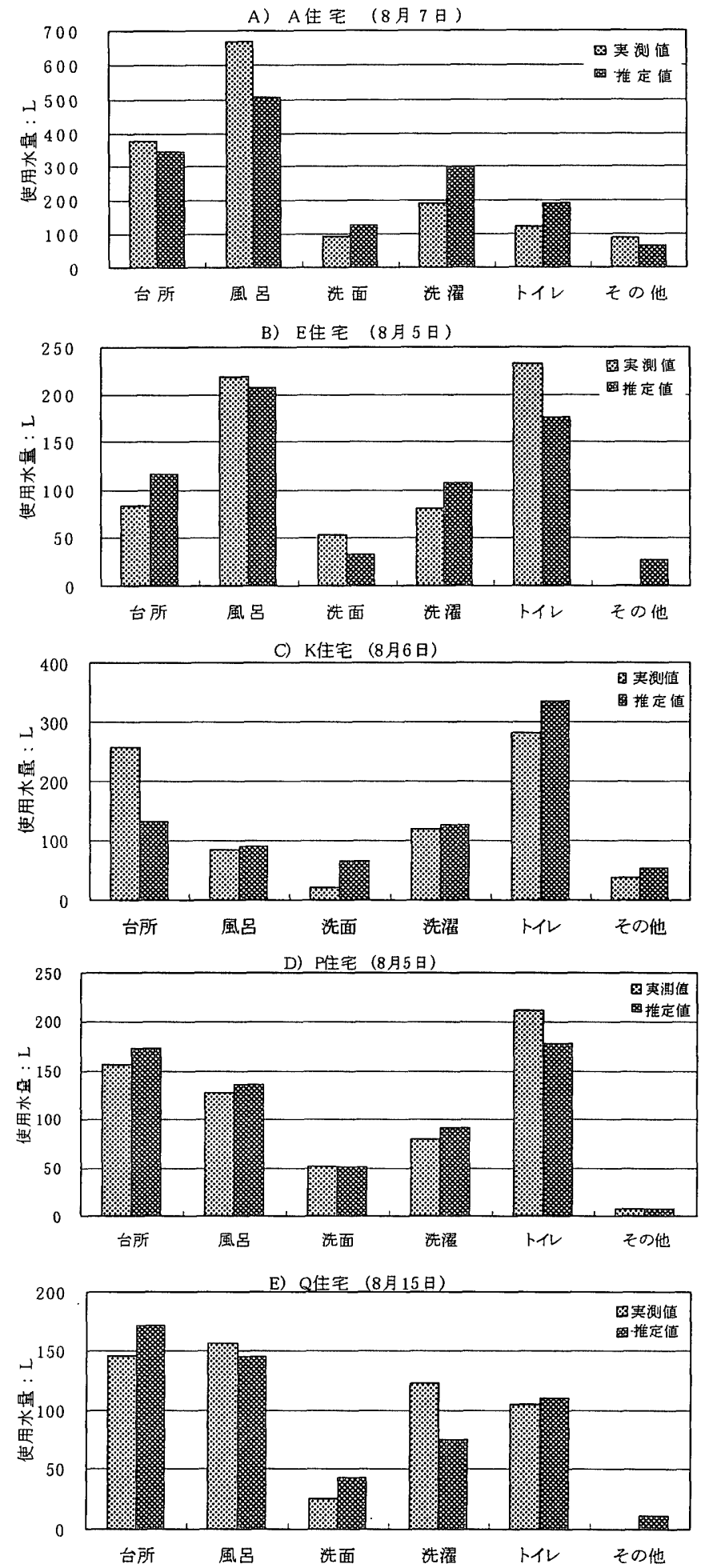

図 6 沉用モデルによる推定結果

表 9 汎用モデルの推定誤差の検定

\begin{tabular}{|c||r|r|r|r|r|r|}
\hline & \multicolumn{1}{|c|}{ 台所 } & \multicolumn{1}{c|}{ 風呂 } & \multicolumn{1}{c|}{ 洗面 } & \multicolumn{1}{l|}{ 洗濯 } & \multicolumn{1}{|c|}{ イイ } & その他 \\
\hline \hline 平均 $[\mathrm{L}]$ & 16.03 & 33.34 & -14.44 & -21.56 & -7.51 & -5.85 \\
\hline 標淮偏差 & 65.51 & 71.15 & 25.39 & 57.29 & 54.29 & 19.58 \\
\hline 標本数 & 5 & 5 & 5 & 5 & 5 & 5 \\
\hline T值 & 0.55 & 1.05 & -1.27 & -0.84 & -0.31 & -0.67 \\
\hline
\end{tabular}


表 10 各ユニット間のシナブス結合荷重（汎用モデル）

\begin{tabular}{|c|c|c|c|c|c|c|c|c|c|c|c|c|c|}
\hline & \multicolumn{12}{|c|}{ 中間層 } \\
\hline & & NO. 1 & NO. 2 & NO. 3 & NO. 4 & NO. 5 & NO. 6 & NO. 7 & NO. 8 & NO. 9 & NO. 10 & NO. 11 & Bias \\
\hline \multirow{6}{*}{ 入力層 } & 居住者数 & -3.49 & -1.86 & -54.64 & 4.72 & -12.04 & -2.94 & 35.52 & -1.81 & 48.44 & -7.31 & 10.48 & - \\
\hline & 使用時間 & -1429.62 & 3.63 & -166.24 & 498.97 & -56.71 & 204.83 & -388.10 & -12.59 & 248.01 & -11.96 & 3.73 & - \\
\hline & 使用水量 & 8421.31 & -6.36 & 503.99 & -2077.56 & 176.68 & -152.98 & 4720.55 & 32.57 & -429.34 & 16.40 & -600.02 & - \\
\hline & 標準偏差 & 603.41 & -8.14 & -69.76 & 226.84 & 59.20 & 57.81 & -403.80 & 26.42 & 699.28 & 6.97 & -222.33 & - \\
\hline & 推定最大值 & -1191.24 & 20.41 & 198.95 & 27.50 & -124.02 & -56.77 & -349.01 & -56.10 & -1025.52 & 6.27 & $276: 98$ & - \\
\hline & Bias & 53.29 & -1.81 & -10.16 & -16.81 & 24.43 & 1.28 & 22.65 & 8.43 & 11.23 & 0.71 & -8.05 & - \\
\hline \multirow{6}{*}{ 出力層 } & 台所 & -0.19 & 0.85 & -0.68 & -0.54 & 0.24 & 0.39 & -0.51 & -0.31 & 0.45 & -0.24 & 0.19 & 0.43 \\
\hline & 風呂 & -0.07 & 1.57 & 0.35 & -0.10 & -0.45 & 0.07 & 0.07 & 1.29 & -0.01 & -0.76 & 0.15 & -1.03 \\
\hline & 洗面 & -0.15 & -1.67 & 0.18 & -0.12 & -0.05 & -0.25 & 0.04 & -0.26 & -0.46 & 0.53 & -0.02 & 1.40 \\
\hline & 洗濯 & -0.06 & -0.65 & 0.15 & -0.00 & 0.59 & -0.06 & 0.04 & -1.04 & 0.01 & 0.03 & -0.07 & 0.62 \\
\hline & トイレ & 0.52 & -0.21 & -0.05 & 0.78 & -0.28 & -0.03 & 0.29 & 0.23 & -0.03 & 0.35 & -0.27 & -0.42 \\
\hline & その他 & -0.05 & 0.12 & 0.04 & -0.01 & -0.06 & -0.11 & 0.06 & 0.10 & 0.03 & 0.09 & 0.02 & 0.00 \\
\hline
\end{tabular}

きたい。また、学習に用いなかった住宅へも拡張して適用できるよ うに、さらに多くの住宅に検討を進め、モデルの一般性と拡張性を 高めていきたい。

\section{参考文献}

1)「東京水道新世紀構想 STEP 21 」、東京都水道局、1997.5

2) 伊藤博、「中小規模集合住宅における瞬時最大流量の解析と算 定法」、水道協会雑誌、第 64 巻、第 11 号（第 734 号）

3) 村川三郎、「集合住宅における水使用之給水負荷算定法」、空 気調和・衛生工学、第 58 巻、第 1 号

4) 中原美和、西貴史、折田信生、紀谷文樹、「モニター住戸にお ける給水・給湯系統の流量特性」、空気調和・衛生工学会学術講演 会講演論文集、PP. 533-PP. 536、1998. 8

5) 豊田秀樹、「非線形多変量解析 ニューラルネットワークによ るアプローチ」、朝倉書店、1996.2

6）鈴木義一郎、「情報量基準による統計解析入門」、講談社、1995.4

7 ）石村貞夫、「すぐわかる統計解析」、東京図書、1993.2
8 ）紀谷文樹、泉忠之、「給排水の管径設計基礎理論（3）」、空気 調和・衛生工学、第 51 巻、第 6 号

9）紀谷文樹、泉忠之、「給排水の管径設計基礎理論（4）」、空気 調和・衛生工学、第 51 巻、第 7 号

10）「事務所・庁舎ビルの用途別使用水量について」、空気調和・ 衛生工学、第 54 巻、第 8 号

11）中山三郎、紀谷文樹、高橋紀行、「事務所建築における使用水 量調查と解析」、空気調和・衛生工学、第 47 巻、第 11 号

12）空気調和 - 衛生工学会編：HASS 206 -1991 給排水設備規準 同解説、1992 年

13）市橋秀友：最大值を 1 と寸る重要度の基準化について、第 5 回 ファジィシステムシンポジウム講演論文集、PP. 307-PP. 312、1989.6 14）林勲、古橋武、「ファジィ・ニューラルネットワーク」、朝倉 書店、1996. 5

15）小野田崇、「階層型ニューラルネットワークの情報量基準」、 人工知能学会誌 VOL. 11 No. 4、PP. 574-PP. 584、1996.7

（1999年 2 月10日原稿受理，1999年 8 月16日採用決定） 